University of Nebraska - Lincoln

DigitalCommons@University of Nebraska - Lincoln

Faculty Publications, Department of Psychology

Psychology, Department of

June 2000

\title{
Social Change and Adolescent Development: Issues and Challenges
}

Lisa J. Crockett

University of Nebraska-Lincoln, ecrockett1@unl.edu

Rainer K. Silbereisen

Friedrich-Schiller University of Jena

Follow this and additional works at: https://digitalcommons.unl.edu/psychfacpub

Part of the Psychiatry and Psychology Commons

Crockett, Lisa J. and Silbereisen, Rainer K., "Social Change and Adolescent Development: Issues and Challenges" (2000). Faculty Publications, Department of Psychology. 243.

https://digitalcommons.unl.edu/psychfacpub/243

This Article is brought to you for free and open access by the Psychology, Department of at DigitalCommons@University of Nebraska - Lincoln. It has been accepted for inclusion in Faculty Publications, Department of Psychology by an authorized administrator of DigitalCommons@University of Nebraska - Lincoln. 


\section{Negotiating Adolescence in Times of Social Change}

Edited by

LISA J. CROCKETT

University of Nebraska-Lincoln

RAINER K. SILBEREISEN

Friedrich-Schiller University of Jena 


\section{Social Change and Adolescent Development: Issues and Challenges}

\section{Lisa J. Crockett and Rainer K. Silbereisen}

Like other phases of the life span, adolescence is shaped by the sociocultural context in which it occurs. The skills young people are expected to master, the kinds of choices they must make, and the settings they negotiate during the adolescent years are prescribed by social institutions (e.g., the educational system) and by shared expectations concerning the requirements for success in adulthood (Crockett, 1997). Social change, which entails large-scale alterations in ideological, technological, and economic systems within societies, has significant implications for adolescent development. For example, social change can affect the structure and dynamics of social contexts that adolescents experience on a daily basis such as family, school, and youth groups. It can also alter the social institutions and cultural belief systems that organize the adolescent period.

Social change has diverse origins. In some cases, change is spurred by pivotal historical events that can abruptly alter the opportunity matrix for young people's development. Examples include political revolutions such as the break-up of the former Eastern bloc, ethnic conflicts as exemplified in the Balkans, immigration, religious movements such as the fundamentalist upsurge in several Islamic countries, and technological breakthroughs that reorient large segments of the economy. In other cases, changes in social organization occur more gradually as with the post-World War II increase in women's labor force participation, the recent rise in divorce, and the growing proportion of elderly in many industrialized countries.

Determining the consequences of such societal-level changes for adolescent development presents formidable challenges. Social change on one or more dimensions must be documented, the complex processes through which social change may affect adolescents must be identified, and the hypothesized causal processes must be linked empirically to adolescent outcomes. In this chapter, we discuss these challenges and the conceptual issues they raise. We begin with one example of social change and use it as a springboard for discussing four questions:

1. What kinds of contextual changes are produced by social change?

2. How (through what mediating processes) do these changes affect adolescent development and well-being? 
3. What individual and contextual factors appear to moderate these processes and their outcomes?

4. What are the implications of social change for adolescent adjustment?

Finally, we outline the organization of the present volume as it relates to these issues.

\section{The Great Depression: An Example of Social Change}

The myriad pathways through which social change affects adolescent development are illustrated in Elder's studies of the Great Depression (Elder, 1974). During the 1930s, the economic downturn created financial strains for many families in the United States. To cope with hardships such as decreased earnings and loss of credit, families had to reduce expenses and find ways to generate additional income. In response to this need, adolescent boys initiated income-earning activities earlier than usual by finding work outside the home. Adolescent girls contributed to the family economy by helping their mothers produce goods for the family's use. These two kinds of work brought differential rewards. As a consequence of working for pay, boys gained independence from parental supervision, exhibited more autonomous behavior, and developed higher self-esteem. In contrast, the work of girls was unpaid, and thus they had no personal earnings to buy goods (e.g., nice clothes) that would have increased their status in the peer group. Moreover, rather than increasing their independence, girls' work tied them firmly to home. Thus, girls did not experience the benefits of working that accrued to boys. Although boys and girls both had to adapt to family hardship resulting from the economic downturn, the roles available to boys and girls differed, fostering different experiences.

The long-term consequences of early economic disadvantage also differed for adolescent boys and girls. Most of the boys served in World War II and profited from postwar educational benefits (the GI Bill). As a result, many had career achievements comparable to peers whose families had not suffered economically during the Depression. In contrast, economically disadvantaged girls tended to marry early and devote themselves to raising children. Many girls entered the labor force during World War II but were subsequently laid off to provide jobs for returning veterans. Although their lives were in keeping with the prevailing social norms of the 1950s, these women exhibited psychological disadvantage relative to peers as reflected in poorer self-esteem and mental health (Elder, 1974). Thus, adult opportunity structures, which differed for males and females, interacted with adolescent experiences to shape the lives and adjustment of Depression-era adolescents.

Apart from altering adolescents' economic roles within the family, financial pressures during the Depression often disrupted family relationships and parenting. Strains related to job loss, bankruptcy, and depleted savings frequently led to marital disputes. Marital clashes, in turn, resulted in a deterioration in family climate and parental socialization efforts. Not surprisingly, such repercussions were associated 
with lower psychological well-being in the children. Notably, marital clashes and disputes were exacerbated if the father showed explosive tendencies initially or had a difficult temperament. The financial crisis accentuated these personality attributes, increasing the hostility experienced by the children (Caspi \& Bem, 1990; Elder \& Caspi, 1990). Thus, although family functioning mediated some of the effects of economic pressures on adolescent adjustment, the personality of key players (particularly the accentuation of negative dispositions) was an important moderator of these effects.

This example shows that social change operates at multiple levels, from the immediate social contexts adolescents experience to national alterations in opportunities for employment, military service, and education. These effects, often moderated by the behavior of parents, may alter adolescent development in myriad ways, for example, by affecting family roles and relationships, by delaying or accelerating entry into adult work and family roles, or by influencing psychological well-being. In turn, adolescents' experiences affect their subsequent development by interacting with the array of opportunities and risks present in a given historical era to influence adult attainments.

Elder's work also underscored the point that social change can affect people differentially on the basis of such individual characteristics as gender and age. $v$ The differential impact of family economic hardship for adolescent girls and boys has already been described. Additionally, age was found to interact with gender. Whereas adolescent girls were more vulnerable than boys to negative outcomes of family economic hardship, among younger children, boys were the more vulnerable gender (Elder, 1974; see also Werner \& Smith, 1982). Other individual characteristics also proved important for Depression-era adolescents; for example, physically unattractive girls were especially likely to experience paternal rejection under conditions of financial hardship (Elder, Nguyen, \& Caspi, 1985).

In sum, the impact of social change is far from uniform. Economic or political crises such as the Depression do not reach all members of a population equally: Some people are more closely linked to the crisis and more likely to experience its effects. Furthermore, the consequences of an event vary according to age, gender, and other characteristics of the person and social context. Thus, some processes (e.g., family financial pressure) may have differential effects for distinct subgroups of adolescents. Indeed, different processes or mechanisms may be active for such subgroups.

\section{Contextual Changes Produced by Social Change}

Identifying the mechanisms linking social change to adolescent development at a given time and place requires an understanding of the sociocultural context and how it is changing. The ecological and life course perspectives provide insights into the social environment and the elements that may change under conditions of social upheaval. The ecological perspective affords a differentiated view of the environment 
by dividing it into multiple levels that influence each other (Bronfenbrenner, 1979, 1989). The life course perspective identifies the constraints on development imposed by social norms and institutions and elucidates the ways in which individuals negotiate their life course in the context of these social constraints (Elder, 1998; Mayer, 1986). Both perspectives posit a dynamic interplay between individual and social context that shapes the course of development.

From an ecological perspective (Bronfenbrenner, 1979, 1989), adolescent development takes place within the immediate social contexts of everyday life: the family, the peer group, the school, and, increasingly, the adolescent workplace. The roles and relationships within these "microsystems" form the basis of daily interactions between the adolescent and the social environment which, over time, shape individual development. Furthermore, these contexts are embedded in a multilevel environmental structure in which "overarching cultural and social belief systems ... cut across and impinge on multiple microsystems" (Wachs, 1996, p. 796). This suggests that changes in cultural and institutional patterns can influence adolescent development in multiple ways.

First, such changes can alter the structure and dynamics of particular microsystems, as when economic recessions modify family roles and dynamics (Elder, 1974), or when prevailing attitudes about alcohol and other drug use influence norms within the peer group (e.g., Johnston, O'Malley, \& Bachman, 1994).

Second, changing institutional patterns may alter the relationships between microsystems involved in child socialization. For example, the collapse of the Socialist political system in the former East Germany changed the relationship between families and schools. Under the Socialist regime, schools were responsible for socializing children to be good citizens and were required to instill values reflecting a "socialist personality." With unification, the task of fostering personality development became the exclusive province of the family, and the role of schools was limited to teaching cognitive skills. This change in the function of schools was accompanied by a reduction in school-based extracurricular activities, which had been a primary source of afterschool child care. The reduction left many families overwhelmed by the need to organize child supervision and take over unfamiliar socialization activities. Researchers have warned that this breakdown in the coordination between microsystems could produce a "socialization vacuum" (Trommsdorff, Chakkarath, \& Heller, 1996).

Third, distal (i.e., macrosystem) forces such as the status of the job market may also affect adolescents directly. The potential for proximal and distal effects of social change is illustrated by the rise in divorce rates in the United States in the 1960s and 1970s and the related increase in single-parent families (e.g., Hernandez, 1997). On one level, parental divorce alters the family microsystem because the removal of a parent necessarily alters roles and relationships within the family (Hetherington \& Clingempeel, 1992). On another level, the increased number of single-parent families can lead to macrosystem changes that affect adolescents. For example, 
new child support policies in the United States have been initiated to ensure that nonresident parents contribute to the economic support of their children. In sum, an ecological analysis suggests that social change may operate at multiple levels of the adolescent's social context and that alterations at one level may stimulate changes at other levels. Changes at each level can have direct or indirect effects on adolescent adjustment and development.

The life course perspective offers a complementary framework that emphasizes the importance of social norms and institutions in shaping developmental paths. At a very general level, societies provide "rough scripts and casts of characters whose interactions tend to shape individual lives" (Clausen, 1991, p. 805). More concretely, institutions such as the educational system provide fairly well-articulated paths for individuals to follow; for example, the progression from elementary school through secondary school to college. Furthermore, the contingencies operating between institutions support an implicit sequencing of role transitions (i.e., school completion, job entry, marriage, and parenthood) during the transition to adulthood (Hogan \& Astone, 1986). If these contingencies change suddenly in the wake of political or economic events, traditional pathways and timetables may be disrupted, leaving young people to negotiate the transition to adulthood with few institutional supports.

The life course perspective also emphasizes the connection between distinct periods of the life span. Adolescence is viewed as a staging ground for adulthood, a period when young people make decisions (knowingly or unknowingly) that have important implications for their subsequent development (Crockett \& Crouter, 1995). The choices adolescents make (e.g., to attend college or not) affect the opportunities and obstacles they encounter in their adult lives.

The utility of combining the ecological and life course perspectives is evident in cases of radical alterations in political or economic systems. For example, the reunification of Germany, an instance of macrosystem change, produced a marked shift in institutional arrangements in the former Eastern bloc countries. Institutional supports that had guaranteed employment, financial security, health care, and child care collapsed, creating a situation in which traditional routines no longer brought the expected results (Heinz, 1996). Thus, reunification affected the dynamics of such microsystems as family and the workplace, and these effects had implications for individual functioning.

Reunification also affected optimal strategies for managing the transition to adulthood. In the former East Germany, preparing for a profession was institutionalized as an integrated sequence of training experiences, apprenticeships, and employment opportunities. Once young people chose a profession (with strong guidance from parents and teachers), they could slip into an institutional mold and be carried toward a career without the risk of unexpected changes along the way. Moreover, a secure, full-time job was virtually guaranteed. In this context, early vocational choice and commitment were instrumental and brought rewards. In contrast, people in West Germany had more vocational options but without the guarantee of 
secure, full-time jobs; also, technological change was in progress. Under these circumstances, greater flexibility regarding vocational choice was beneficial; it was better to remain open to new information and alert to emerging options than to adhere to firm vocational commitments (Kerpelman, Pittman, \& Lamke, 1997). With unification, adolescents in the former East Germany are now confronting this unfamiliar scenario and will need to adjust their strategies and timetables concerning vocational identity.

In summary, the ecological and life course perspectives provide complementary frameworks for analyzing the impact of social change. Social change can alter the structure and dynamics of everyday contexts such as the family or the relations between these contexts. Moreover, social change can alter the institutions that support particular choices and life paths. Presumably, these changes affect adolescents' development by altering their goals, strategies, and choices.

\section{Mediating Processes: Perceptions, Goals, and Plans}

With age, children become increasingly able to select and shape their environments in ways that influence their development (e.g., Lerner, 1982). Increased capacity in this regard is a hallmark of adolescence; compared with children, adolescents have greater cognitive and behavioral capabilities that enable them to influence their environments. Moreover, in Westernized nations, adolescents are granted increased autonomy to make decisions with long-term consequences (e.g., dropping out of high school, attending college, getting married). Thus, adolescents have considerable opportunity to set goals and plan their future, although there is tremendous variability in how much goal-setting and planning actually occurs. Individuals can use several cognitive mechanisms to shape their development actively, including personal goals, identity, efficacy beliefs, and planful competence (e.g., Brandtstädter, 1997; Clausen, 1991). These processes may mediate the effects of social change on adolescent development.

\section{Personal Goals}

Adolescents set goals that guide their actions and influence their subsequent development. In recent psychological research, concepts such as personal tasks (Little, 1993), life tasks (Cantor, 1994), and personal goals (Nurmi, 1993) have been used to characterize such efforts. These concepts have a problem-solving metaphor in common: adolescents are thought to perceive social expectations and to define tasks for themselves based on these expectations. For example, Nurmi (e.g., 1989) has shown that adolescents' (and adults') personal goals reflect culturally based developmental tasks associated with their phase of life. How adolescents translate these expectations into personal striving is a product of their individual interests, perceptions of viable options, and capacity for strategic planning. Social change may 
alter young people's goals (e.g., by changing the available options, the value placed on particular goals, or the capabilities and credentials required for accomplishing particular goals).

\section{Identity}

The development of personal goals is related to the broader process of identity formation. By many accounts (Erikson, 1968; Havighurst, 1948/1972), forming an identity is the overarching task of adolescence, subsuming more circumscribed tasks such as pursuing one's education, choosing a vocation, or establishing mature relationships with peers. Following Erikson (1968) and more recent work by Marcia (1980) and Waterman (1982), the development of a coherent, integrated sense of self is linked to finding one's niche in society and acquiring a sense of self as existing through time. Young people who have formed an identity know who they are, where they came from, and where they are headed. An identity provides a framework linking personal goals and choices to the life course as a whole.

Some kinds of social change may interfere with the usual process of identity formation. For example, the array of available occupations may change, delaying the formation of a vocational identity. Additionally, some people may experience a disjuncture in their personal biography if past achievements that are central to their identity become irrelevant in the new social order. As an example, the transformation to market economies in former European Socialist countries shifted the nature of the personal and social skills needed for success. Characteristics such as impression management, communication skills, and willingness to take risks and show responsibility became more important than before for both blue and white collar workers (Baethge, Andretta, Naevecke, Rossbach, \& Trier, 1996; Koehler, 1996). Presumably, adolescents perceived these new requirements and reoriented their goals accordingly. By inducing new personal goals, social change affected identity formation and other aspects of development.

\section{Self-Efficacy}

Control or efficacy beliefs (Bandura, 1995) represent a third important mechanism of self-produced development. Without the belief that one is able to arrange things in a way that facilitates achievement of one's goals and enhances life satisfaction, the motivation for goal-directed action would be lost (Silbereisen \& Eyferth, 1986). Adolescents who lack such beliefs might withdraw from the challenge of shaping their futures or pursue their goals less energetically or in less cognitively sophisticated ways. Most important, only those convinced of their efficacy will seek out and explore new settings that further stimulate their developmental progress.

Recent experiences in former Eastern bloc countries suggest that social change can influence adolescents' efficacy-related beliefs. Grob et al. (1996) compared 
adolescents from seven Western and seven former Eastern bloc countries in terms of perceived control. They found higher scores among Eastern bloc youth and speculated that the rapid expansion of individual freedom had stimulated an increase in perceptions of personal autonomy and efficacy.

\section{Planful Competence}

Individuals also shape their development through planning. Strategic planning entails more than formulating and pursuing goals; it requires a clear mental representation of a course of action in terms of strategies, sequencing of activities, and so forth. Clausen (1991) reported important differences among adolescents in "planful competence," which is defined as a combination of dependability, intellectual investment, and self-confidence.

Societal change can alter the extent to which planful competence plays a role in young people's future-oriented choices. In a recent study, Shanahan and his colleagues (Shanahan, Elder, \& Miech, 1997) compared two cohorts of gifted men. One cohort faced the poor job prospects of the Depression era; the other encountered the boom economy of the post-World War II period. The different economic milieus were associated with differential effects of planful competence. Men of the older cohort tended to stay in school regardless of their level of planful competence, apparently waiting for better times. In contrast, planfully competent men in the later cohort received more education than their less planful peers. Evidently, the limited employment opportunities of the Depression constrained behavioral choices, reducing the role of planful competence in men's educational decisions.

The foregoing suggests a general model of the processes mediating social change effects. Social change entails alterations in cultural beliefs, social institutions, or both. Changes at this more distal level affect operations within immediate social contexts (microsystems) as well as the beliefs espoused by parents, peers, and the media. In turn, altered roles, relationships and practices within proximal social contexts, in conjunction with perceptions of economic opportunities and vocational options, are likely to influence adolescents' personal goals, strategies for attaining their goals, identity, self-efficacy beliefs, and planful competence. These perceptions are then translated into actions and choices that shape subsequent development.

\section{Moderators of Social Change Effects}

As noted earlier, the effects of social change do not apply uniformly to an entire population. Rather, effects vary as a function of the individual's age or developmental status at the time of the social transformation. A contemporary example comes from research on values in East and West Germany after unification. The difference in collectivist values was small in 1991, but even smaller by 1996, reflecting the effects of unification (Reitzle \& Silbereisen, 1997). However, the decrease in 
collectivist values among former East Germans was not uniform. Rather, those who were adolescents at the time of unification (and had spent their adolescent "impressionable" years under East German conditions) showed less change in attitudes than those who were younger at the time of unification. ${ }^{1}$ More broadly, personal characteristics such as gender, ethnicity, temperament, and other "developmentally instigative" characteristics (Bronfenbrenner, 1989) condition how people respond to an individual and how the individual engages the social world. These characteristics moderate the effects of social change on development.

For example, psychological characteristics such as self-efficacy and locus of control alter the impact of social change. Among former East Germans, individuals who exhibited higher internal control beliefs were generally more successful following unification than their peers, particularly regarding employment (Diewald, Huinink, $\&$ Heckhausen, 1996). Thus, an internal locus of control served a protective function in the wake of social upheaval.

\section{Implications for Adolescent Adjustment}

Social change is expected to have implications for adolescent development and adjustment. Although some degree of social change is characteristic of modern industrialized societies, changes that alter the organization of social life are presumed to present major adaptive challenges that can overburden the coping capacities of some young people. This should be especially true when young people are also attempting to cope with the normative changes of adolescence or with nonnormative life events such as parental death (e.g., Petersen, 1987). Certainly, the degree of challenge depends on the scale, rate, and pervasiveness of change: Large-scale political reorganizations that permeate all levels of society may have greater effects than more circumscribed changes that primarily affect a single microsystem. Where change is more gradual and limited, most people can find a balance between what worked in the past and what the new situation requires. Thus, the danger lies not in change per se but in rapid, pervasive change.

Further, as is true for most crises, social change implies both risks and opportunities. The balance between these two sides of the coin is not the same across phases of the life span or for individuals who held different social positions before the change. We might expect a less orderly progression to adulthood for many youth during periods of rapid social change and a greater chance of failure en route for those unable to adapt to new demands and take advantage of new opportunities. At the same time, for youth whose projected life course before the change would have been rigidly prescribed and economically limited, the disruption in normative patterns opens up new avenues for achievement and personal satisfaction. As noted earlier, the impact of such societal changes will also depend in part on characteristics of the individual (temperamental, social, cognitive) that affect the ways in which adolescents negotiate the changing social, political, and economic landscape. 
In summary, social change can be studied as a natural experiment in which the social parameters that sustain normative developmental patterns are in flux. By examining these changes and assessing their impact on adolescent development, we can learn which parameters comprise critical social supports. Furthermore, because rapid, large-scale social change is presumably stressful (disrupting institutional contingencies and creating uncertainty about optimal courses of action), the study of social change enables a look at the impact of stress on adolescent functioning and the identification of factors that may enhance resilience.

\section{Organization of the Present Volume}

The implications of social change for adolescent development and the processes through which effects of social change occur are the subject of the present volume. Currently, we know little about the diverse ways in which social change affects adolescence, the mechanisms involved, and the impact of distinct kinds of social change (e.g., limited or pervasive). Equally important, there is limited information on the role of individual characteristics in determining adolescents' responses to social change, although some research has begun to address this issue with adults (Bandura, 1995). Thus, we do not know which characteristics may be most beneficial in helping young people cope successfully.

This volume is organized around several themes emerging from the preceding discussion: models of social change effects, implications of social change for the nature and timing of adolescent transitions, impact of social change on immediate contexts (family, peer group, and neighborhood), the relation of social change to adolescent health and well-being, and implications for social intervention. In the first section, Elder and Russell offer a multilevel model of the intersection of social change and individual lives; they provide a "road map" of the points at which social change affects individual development. The chapter by Brooks-Gunn and colleagues examines social change through the lens of intergenerational differences in teenage childbearing. The commentary chapter by Trommsdorff offers a complementary model of social change effects that emphasizes the role of the individual's subjective experience.

The second section addresses the implications of social change for the nature and timing of adolescents' developmental transitions. Schlegel focuses on adolescents' ability to borrow cultural forms (e.g., traditions) from other societies and incorporate them into their own developmental transitions, thereby participating in the production of social change. Bynner shows that the nature and timing of adolescents' developmental transitions are altered as a side effect of social change, and that these alterations have differential consequences for adolescents who occupy distinct positions in the social structure. The chapter by Silbereisen compares the timing of developmental transitions in former East and West Germany after unification and shows that East-West differences in individual timetables reflect the distinct institutional patterns that existed before unification. The commentary 
chapter by Shanahan and Hood focuses on human agency and its role in adolescents' responses to social change.

The third section tackles the impact of social change on particular social contexts. Noack examines the role of unification on adolescent peer groups and norms and notes that similar cultural practices can yield different outcomes in different settings. Bertram shows that the distribution of family types (singles, married couples, widows) has changed over the 20th century and that this has potential implications for adolescent development. Sampson discusses the changing neighborhood patterns affecting some U.S. cities and their implications for the control of adolescents and neighborhood crime. The commentary chapter by Flanagan highlights the active role of adolescents as agents of social change.

The fourth section addresses the issue of adolescent health. Conger and colleagues summarize their tests of a path model linking family economic pressure to marital distress, parent-child interaction, and adolescent emotional well-being. Schulenberg and colleagues examine adolescent well-being across multiple U.S. cohorts and find that post-high school changes in psychological well-being and substance use are largely similar for cohorts who graduated between the mid-1970s and mid-1990s. In his commentary, Boehnke discusses the challenge of capturing social change through the study of cohorts.

The fifth section applies our emerging knowledge of social change to the design and implementation of interventions aimed at fostering healthy adolescent development. The dilemma is how to prepare youth for adulthood when ongoing social change makes the future difficult to predict. Hamilton and Hamilton argue for better coordination among the various institutions that adolescents must navigate, especially the school-to-work-transition. Takanishi focuses on "basic survival skills" needed to make a successful transition to adulthood and identifies general strategies for social intervention. In her commentary chapter, Petersen identifies the challenge of preparing youth for a future that cannot be fully divined and emphasizes the importance of family and community in supporting a successful transition to adulthood in times of social change.

\section{References}

Alwin, D. F. (1994). Aging, personality, and social change: The stability of individual differences over the adult life span. In D. L. Featherman, R. M. Lerner, \& M. Perlmutter (Eds.), Life-span development and behavior, Vol. 12 (pp. 135-185). Hillsdale, NJ: Erlbaum.

Baethge, M., Andretta, G., Naevecke, S., Rossbach, U., \& Trier, M. (1996). Die berufliche Transformation in den neuen Bundesländern [The transformation of occupational demands in the new federal states]. Münster: Waxmann.

Bandura, A. (1995). Exercise of personal and collective efficacy in changing societies. In A. Bandura (Ed.), Self-efficacy in changing societies (pp. 1-45). Cambridge, England: Cambridge University Press.

Brandtstädter, J. (1997). Action perspectives on human development. In W. Damon (Ed.), Handbook of child psychology: Vol. 1. Theoretical models of human development (5th ed. pp. 807-863).

New York: Wiley. 
Bronfenbrenner, U. (1979). The ecology of human development: Experiments by nature and design. Cambridge, MA: Harvard University Press.

Bronfenbrenner, U. (1989, April). The developing ecology of human development: Paradigm lost or paradigm regained? Paper presented at the biennial meeting of the Society for Research in Child Development, Kansas City, MO.

Cantor, N. (1994). Life task problem solving: Situational affordances and personal needs. Personality and Social Psychology Bulletin, 20, 235-243.

Caspi, A., \& Bem, D. (1990). Personality continuity and change across the life course. In L. Pervin (Ed.), Handbook of personality (pp. 549-575). New York: Guilford Press.

Clausen, J. S. (1991). Adolescent competence and the shaping of the life course. American Journal of Sociology, 96, 805-842.

Crockett, L. J. (1997). Cultural, historical, and subcultural contexts of adolescence: Implications for health and development. In J. Schulenbery, J. L. Maggs, \& K. Hurrelmann (Eds.), Health risks and development during adolescence (pp. 23-53). Cambridge, England: Cambridge University Press.

Crockett, L. J., \& Crouter, A. C. (1995). Pathways through adolescence: An overview. In L. J. Crockett \& A. C. Crouter (Eds.), Pathways through adolescence: Individual developmental in relation to social contexts (pp. 1-12). Mahwah, NJ: Lawrence Erlbaum Associates.

Diewald, M., Huinink, J., \& Heckhausen, J. (1996). Lebensverläufe und Persönlichkeitsentwicklung im gesellschaftlichen Umbruch. Kohortenschicksale und Kontrollverhalten in Ostdeutschland nach der Wende [Life histories and developmental control in times of macrosocial ruptures: The case of different birth cohorts in the transformation process in Eastern Germany]. Kölner Zeitschrift für Soziologie und Sozialpsychologie, 48, 219-248.

Elder, G. H., Jr. (1974). Children of the Great Depression: Social change in life experience. Chicago: University of Chicago Press.

Elder, G. H., Jr. (1998). The life course and human development. In W. Damon (Series Ed.) \& R. Lerner (Vol. Ed.), Handbook of child psychology: Vol. 1. Theoretical models of human development (5th ed., pp. 939-991). New York: Wiley.

Elder, G. H., Jr., \& Caspi, A. (1990). Studying lives in a changing society: Sociological and personological explorations. In A. I. Rabin., R. A. Zucker, \& S. Frank (Eds.), Studying persons and lives (pp. 201-247). New York: Springer-Verlag.

Elder, G. H., Jr., Nguyen, T. V., \& Caspi, A. (1985). Linking family hardship to children's lives. Child Development, 56, 361-375.

Erikson (1968). Identity: Youth and crisis. New York: Norton.

Grob, A., Little, T. D., Wanner, B., \& Wearing, A. J. (1996). Adolescents' well-being and perceived control across 14 sociocultural contexts. Journal of Personality and Social Psychology, 71, 785-795.

Havighurst, R. J. (1948/72). Developmental tasks and education (3rd ed.). New York: McKay.

Heinz, W. (1996). Berufsverläufe im Transformationsprozess [Occupational trajectories during the social and political transformations]. In S. E. Hormuth, W. R. Heinz, H.-J. Kornadt, H. Sydow, \& G. Trommsdorff (Eds.), Individuelle Entwicklung, Bildung und Berufsverläufe (pp. 273-358). Opladen, Germany: Leske \& Budrich.

Hernandez, D. J. (1997). Child development and the social demography of childhood. Child Development, 68, 149-169.

Hetherington, E. M., \& Clingempeel, W. G. (1992). Coping with marital transitions. Monographs of the Society for Research in Child Development, 57 (Serial No. 227).

Hogan, D. P., \& Astone, N. M. (1986). The transition to adulthood. Annual Review of Sociology, 12, $109-130$.

Johnston, L. D., O'Malley, P. M., \& Bachman, J. G. (1994). Drug use among American high school students: National trends through 1993. Rockville, MD: National Institute of Drug Abuse.

Kerpelman, J. L., Pittman, J. F., \& Lamke, L. K. (1997). Toward a microprocess perspective on adolescent identity development: An identity control theory approach. Journal of Adolescent Research, 12, 325-346.

Koehler, T. (1996). Managementkultur Ost und West: Zur personalen Situation des leitenden Managements in der Region Ostthüringen [Management culture East and West: The personal situation of upper level managers in the eastern Thuringia region]. In W. Frindte, T. Fahrig, \& T. Koehler, Deutsch-deutsche Spiele. Münster, Germany: Lit. 
Lerner, R. M. (1982). Children and adolescents as producers of their own development. Developmental Review, 2, 342-370.

Little, B. R. (1993). Personal projects and the distributed self: Aspects of a conative psychology. In J. Suls (Ed.), Psychological perspectives on the self (pp. 157-185). Hillsdale, NJ: Erlbaum.

Marcia, J. (1980). Identity in adolescence. In J. Adelson (Ed.), Handbook of adolescent psychology (pp. 159-187). New York: Wiley.

Mayer, K. U. (1986). Structural constraints on the life course. Human Development, 29(3), 163-170.

Nurmi, J. E. (1989). Development of orientation to the future during early adolescence: A four-year longitudinal study and two cross-sectional comparisons. International Journal of Psychology, 24, 195-214.

Nurmi, J. E. (1993). Adolescent development in an age-graded context: The role of personal beliefs, goals, and strategies in the tackling of developmental tasks and standards. International Journal of Behavioral Development, 16, 169-189.

Petersen, A. C. (1987). The nature of biological-psychosocial interactions: The sample case of early adolescence. In R. M. Lerner \& T. T. Foch (Eds.), Biological-psychosocial interactions in early adolescence (pp. 35-61). Hillsdale, NJ: Lawrence Erlbaum Associates.

Reitzle, M., \& Silbereisen, R. K. (1997, April). Adapting to social change: Adolescents' values in Eastern and Western Germany. Paper presented at the Biennial Meeting of the Society for Research in Child Development, Washington, DC.

Shanahan, M. J., Elder, G. H., \& Miech, R. A., (1997). History and agency in men's lives: Pathways to achievement in cohort perspective. Sociology of Education, 70, 54-67.

Silbereisen, R. K., \& Eyferth, K. (1986). Development as action in context. In R. K. Silbereisen, K. Eyferth, \& G. Rudinger (Eds.), Development as action in context: Problem behavior and normal youth development (pp. 3-16). New York: Springer-Verlag.

Trommsdorff, G., Chakkarath, P., \& Heller, P. (1996). Kindheit im Transformationsprozess [Childhood during the process of social and political transformation]. In S. E. Hormuth, W. R. Heinz, H.-J. Kornadt, H. Sydow, \& G. Trommsdorff (Eds.), Individuelle Entwicklung, Bildung und Berufsverläufe (pp. 11-78). Opladen, Germany: Leske \& Budrich.

Wachs, T. D. (1996). Known and potential processes underlying developmental trajectories in childhood and adolescence. Developmental Psychology, 32, 697-801.

Waterman, A. (1982). Identity development from adolescent to adulthood: An extension of theory and a review of research. Developmental Psychology, 18, 341-358.

Werner, E. E., \& Smith, R. (1982). Vulnerable but invincible: A longitudinal study of children and youth. New York: McGraw-Hill. 